\title{
Geographies of Production: Growth Regimes in Spatial Perspective 3 - Toward a Relational View of Economic Action and Policy
}

\author{
Harald Bathelt
}

\begin{abstract}
Version Post-print/accepted manuscript
Citation Bathelt, H. (2006). Geographies of production: Growth regimes in

(published version) spatial perspective 3 - Toward a relational view of economic action and policy. Progress in Human Geography, 30(2), 223-236.
\end{abstract}

Copyright / License

Publisher's Statement

The version of record [Bathelt, H. (2006). Geographies of production: Growth regimes in spatial perspective 3 - Toward a relational view of economic action and policy. Progress in Human Geography, 30(2), 223-236.] is available online at: http://phg.sagepub.com/content/30/2/223 [doi: 10.1191/0309132506ph603pr]

Always cite the published version, so the author(s) will receive recognition through services that track citation counts, e.g. Scopus. If you need to cite the page number of the TSpace version (original manuscript or accepted manuscript) because you cannot access the published version, then cite the TSpace version in addition to the published version using the permanent URI (handle) found on the record page. 
June 28, 2005

Word count: ca. 4900 words (excl. references and notes)

\section{Geographies of production:}

\section{growth regimes in spatial perspective 3 - \\ toward a relational view of economic action and policy}

\section{Harald Bathelt}

Faculty of Geography, Philipps-University of Marburg,

Deutschhausstraße 10, D-35032 Marburg,

Germany

Progress Report on "Geographies of Production"

Forthcoming in

Progress in Human Geography 2006 


\section{What's next? Turns and open debates in economic geography}

Since the 1990s, the basic foundations and core ideas of economic geography have been under intensive scrutiny. Besides a fundamental critique of traditional approaches, several turns have been postulated which have argued for a need to rejuvenate, reorient or radically restructure the field. This debate was, in part, initiated by Paul Krugman and some fellow economists who suggested a 'new economic geography' (e.g. Krugman, 1991; Fujita, Krugman and Venables, 1999). This work has also been interpreted as an 'economic turn' in the discipline. The corresponding approaches would, however, be better classified as 'geographical economics' because they are primarily directed toward the field of economics. They do not provide a broad basis for research in economic geography and focus too closely on quantifiable factors, while neglecting the complex social realities of economic life (Martin and Sunley, 1996; Bathelt, 2001).

Nonetheless, this has stimulated debate about the research goals of and methodology in economic geography. Some have claimed that there is a need for an 'institutional turn' (Amin, 1999; 2002) or a 'cultural turn' (Crang, 1997; Thrift, 2000a). Amin and Thrift's (2000) provoking critique of contemporary economic geography, in which they propose a shift in focus away from economics toward a cultural geography of the economy, has stimulated a vivid discussion and sharp criticism (e.g. Martin and Sunley, 2001; Rodríguez-Pose, 2001). Although recognising some important progress in the work of geographical economists, many economic geographers, such as Scott (2004), do not view this as a long-term perspective of the discipline. At the same time, they also do not support a cultural turn. ${ }^{1}$

The problem of these turns is that they are guided by political arguments and opinions which lead to conflict between different fields. In principle, the question is raised as to which discipline is best suited to understand the contemporary economic world. Each turn favours some influences of the social and economic reality while neglecting others. Aside from 
normative debate, there have been distinctive tendencies in economic geography to take new directions that differ from traditional approaches. I would refer to this as a trend toward a relational approach in economic geography. This should not be viewed as another turn, because it does not try to isolate those aspects of human life which are inseparable (see, also, Hudson, 2004). It integrates economic and social, cultural, institutional and political aspects of human agency (Bathelt and Glückler, 2003).

The point of departure of this re-conceptualisation is the structural problems in traditional approaches which serve as a barrier to understanding economic processes. On the one hand, traditional approaches tend to focus on regions and other spatial representations and the identification of their economic attributes (Massey, 1985). Regions are treated as if they are actors while the real agents, i.e. those people who act and interact in firms and other organisations to produce economic value, are often neglected (Swyngedouw, 1997; Maskell, 2001a). On the other hand, traditional approaches often use spatial variables related to distance as explanatory factors to understand location decisions and spatial distributions of economic activities (Sheppard, 2000; Barnes, 2001). ${ }^{2}$ Such research has tended to neglect the role of agents who actively shape their environment through processes of involving local partners in production, training workers and putting pressure on policy makers to implement support policies (Storper and Walker, 1989).

These and other problems (e.g. Sayer, 2000) have caused many scholars to rethink the foundations of economic geography. As a consequence, a relational perspective has developed which is based on a micro-level approach, focusing on the actors in those economic and social processes which result in agglomeration, economic specialisation, uneven development, etc. ${ }^{3}$ Having critically discussed aspects concerning the conceptualisation of particular growth regimes in spatial perspective in my prior progress reports (Bathelt 2003; 2005a), I argue that a relational perspective in economic geography is 
particularly well-suited to conceptualise economic action and policy in spatial perspective. As opposed to traditional views, this approach allows us to analyse the consequences of global interdependencies and their relation to processes of local concentration and specialization. The goal of this report is not to argue that the discipline proceeds in a linear way (see, also, Scott, 2000). I aim to review the tendencies toward a relational perspective of economic geography and discuss some open issues related to this. As will be shown in the next section, this development is not radically new and consists of many different streams with varying theoretical and empirical orientations.

\section{Toward relational thinking}

The changes which have been made in the research designs in economic geography since the 1980s have substantially helped to ameliorate the above-mentioned problems. In this report, I interpret this as a shift toward a relational conceptualisation of economic action in spatial perspective. As shown below, different individuals and research groups can be distinguished which have developed similar ideas in this respect. Although not all might view their work as being part of a relational approach, their research shares important characteristics and understandings (Yeung, 2005). This work is characterised by the following commonalities (e.g. Bathelt and Glückler, 2002; 2003; Boggs and Rantisi, 2003; Ettlinger, 2003): (i) a focus on economic agency instead of spatial representations, (ii) a micro-level reasoning, often supported by extensive interview-based empirical work, ${ }^{4}$ (iii) an institutional focus in analysing stabilisations of economic relations, (iv) a strong tendency to move beyond spatial description in order to provide a deeper understanding of social and economic processes, (v) an analysis of the effects of globalisation on economic organisation and the resulting global-local tensions, and (vi) a development of pro-active regional policy perspectives (e.g. Cooke and Morgan, 1998; Asheim and Herstad, 2003) based on an actor network focus. 
When trying to trace the roots of relational thinking, it is striking to see how many individuals and research groups have developed ideas which have much in common with the views and attitudes expressed in this paper. Sometimes, these developments have occurred simultaneously, sometimes independently. It is impossible to quote all different streams which share similar ideas about the foundations of research in economic geography. As a consequence, my simplified sketch will be restricted to those people who have had a strong impact on my own thinking. Of course, the subsequent interpretation of their work does not necessarily correspond with their original intentions.

Since the early 1980s, there have been numerous individuals who recognised that economic action is strongly shaped by the particular context within which it takes place and that firms operating, for instance, in a setting of industrial restructuring can employ different strategies to overcome crisis. Gordon Clark, for instance, expressed ideas which reject the notion of spatial determinism in this context (e.g. Clark, 1983). This has been developed further into an agency-centred approach in economic geography (Clark and Tracey, 2004) and scepticism toward over-generalisation in using abstract theories (Clark, 2005). Another important influence is Andrew Sayer, particularly through his work on contingency in economic action and critical realism (e.g. Sayer, 1992; 2000).

At about the same time, Doreen Massey, Nigel Thrift and, later also, Ash Amin and others separately or jointly rejected the idea of conceptualising economic geography as a spatial science which neglects the economic and social realities of economic action (e.g. Massey, 1985; Amin, 1994). Meanwhile, their work has developed further to include, for instance, sophisticated actor-network conceptions, de-territorialized views of knowledge creation and the relational construction of spatial identity (e.g. Thrift, 2000b; Allen, 2003; Massey, 2004; Amin and Cohendet, 2004). Some of this work has become constitutive for the 
'cultural turn' in economic geography (e.g. Thrift, 2000a; Lee, 2002; Amin and Thrift, 2003).$^{5}$

Parallel to the developments in the U.K., a Californian school of economic geography developed around Allen Scott, Michael Storper and Richard Walker in the early 1980s. In this work, the space-creating forces of economic agents and windows of locational opportunity are the focus of attention, fundamentally breaking up the deterministic spatial logic of traditional approaches (e.g. Walker and Storper, 1981; Scott, 1988; Storper and Walker, 1989). In more recent work, Storper (1997) has introduced the concept of untraded interdependencies to explain the genesis and growth of industry agglomerations (see, also, Storper and Venables, 2004), as opposed to traded interdependencies which are the focus of traditional approaches. In his conceptualisation of the 'holy trinity', Storper (1997) views technology, organisation and territory as three overlapping constituent pillars which help understand regional worlds of production. ${ }^{6}$

This and other work have influenced what could be called the Manchester school of global production chains around Peter Dicken, Neil Coe, Martin Hess, Henry Yeung and others. The work of this group fundamentally builds upon a network conception of economic action (Yeung, 1998) which emphasises global connectivities (e.g. Dicken, Kelly, Olds and Yeung, 2001; Dicken and Malmberg, 2001; Henderson, Dicken, Hess, Coe and Yeung, 2002). They suggest a spatial perspective in the analysis of global production networks and criticise the narrow-minded implications of regional analyses. Further, they emphasise aspects of socio-institutional and cultural embeddedness in international economic interaction (Coe and Bunnell, 2003; Dicken, 2005).

The German school of the relational approach initiated by Johannes Glückler and myself (e.g. Bathelt and Glückler, 2002; 2003; Glückler and Bathelt, 2003) developed during the late 1990s. This approach is based on evolutionary and institutional conceptions and focuses on a 
relational conceptualisation of action which is analysed in spatial perspective. The core categories of analysis revolve around interactive learning and organisational, evolutionary and innovation issues. On the one hand, these ideas were based on a critique of the general state of German economic geography ${ }^{7}$ at that time, inspired by the work of the Californian school. ${ }^{8}$ On the other hand, this conceptualisation was shaped by innovative work of other economic geographers during the 1990s, who had already overcome some of the limitations and fallacies of traditional approaches, such as Meric Gertler, Gernot Grabher, Anders Malmberg and Peter Maskell (e.g. Gertler, 1993; 1995; Grabher, 1993; 2002; Maskell and Malmberg, 1999; Malmberg and Maskell, 2002).

At the 2002 annual meetings of the Association of American Geographers (AAG) in Los Angeles, many ideas revolving around relational economic geography were bundled in a series of sessions organised by Jeff Boggs and Norma Rantisi. ${ }^{9}$ This resulted in a special issue of the Journal of Economic Geography in 2003 to give these ideas a broader audience (Boggs and Rantisi, 2003). Not surprisingly, the different relational schools are not fully homogeneous but rather express a variety of disciplinary traditions and views. ${ }^{10}$ Nonetheless, they present a distinct turning point, away from traditional conceptualisations of economic geography.

Using this as a point of departure, the remainder of this report is structured as follows. In section 3, the foundations of a relational approach in economic geography will be developed, integrating economic and social aspects of interaction and analysing them in spatial perspective. Then, some missing links and aspects of the relational approach which need further clarification are discussed. Section 4 deals with aspects of agency and rationalities. In section 5 , the question is raised as to how the relational conception of agency can be complemented by a macro perspective. To address this, the role of institutions is emphasised. 
Finally, section 6 draws some conclusions about the relational consequences for territorial policy making.

\section{Relational action in spatial perspective}

Questions related to how economic action and interaction take place at different locations and between agents in different places are a primary focus of the relational conception in economic geography. As suggested by Bathelt and Glückler (2002; 2003), a relational approach can be conceptualised along the lines of three distinct consequences for economic action and interaction, i.e. contextuality, path-dependence and contingency (see, also, Amin, 1999; Hudson, 2004). First, economic agents are situated in particular contexts of social relations and operate under specific institutional and cultural conditions from which they cannot easily be separated (Polanyi, 1957; Granovetter, 1985). The resulting economic relations can be formal (e.g. contract-based) or informal (e.g. trust-based) in character. Second, economic action is path-dependent in the sense that decisions made in the past influence today's decisions (Dosi, 1988; Nelson, 1995). Third, despite their path-dependent nature, economic processes are not pre-determined. Individual and collective strategies are contingent and can easily lead to deviations from existing structures (Sayer, 1992; 2000).

The consequence of this conceptualisation is that it is not possible to analyse a region independently of the economic and social relations between people and firms which bind them together. This does not imply, however, that spatial proximity automatically leads to the establishment of strong local networks. Instead, it is relational proximity which enables close social interaction and becomes a source of competitiveness (Amin and Cohendet, 2004). Such affinity can also develop between actors located in different parts of the world, supported through modern technological and institutional developments (Bathelt and Glückler, 2002; Allen, 2004). 
Of course, economic geography does not just focus on the analysis of relations. It also aims to understand how actors mobilise physical assets individually or collectively under the conditions of increasing globalisation in a materialistic world. Material resources and classical location conditions necessarily impact economic action and decision making. The intended and unintended results of related economic action, in turn, affect the structure of these resources (e.g. Werlen, 1995; Crevoisier, 2004). This creates a reflexive process through which resources are constantly (re)shaped, becoming important influences thus constituted in a relational way in that they rely on collective processes of resource generation and application (Glückler and Bathelt, 2003).

I would argue that this relational framework enables us to understand the complex realities of economic action and interaction, different from the descriptions in traditional approaches. It requires, however, that our view of the role of space in economic geography be altered. Instead of using space as an explanatory factor or research object, we propose the application of a spatial perspective or geographical lens (Glückler, 1999). This implies that economic geographers define their discipline as a social science (Clark, 2005) which interacts and communicates with other disciplines in social science. This spatial perspective acknowledges that economic action and interaction are always grounded in particular places and the relations between them. As a consequence, fundamental interdependencies between economic, social and cultural processes within and between different places, regions or nation-states are created. Economic activities necessarily interact with other economic and social processes which take place in the same places. The same agents participate in various processes simultaneously. Also, different processes often involve the same group of agents. Processes are necessarily interdependent, either because they take place within the same localities, between the same regions or, exactly, because they do not (Bathelt and Glückler, 2003). In this understanding, proximity is important because it provides opportunities for 
face-to-face contacts (Storper and Venables, 2004) which can be used to develop relational capital (Capello and Faggian, 2005) and stimulate collective learning (Gertler, 2004). By no means, however, learning processes are restricted to particular spatial configurations (Amin, 2004).

Based on these propositions, a micro-level, agency-centred approach toward economic geography (Clark and Tracey, 2004; van Wezemael, 2004) emphasises processes of economic action and interaction which are analysed in spatial perspective. In the area of the geography of the firm, this includes the analysis of (i) organisational forms which enable a more or less efficient division and integration of labour and their variation from place to place (Sayer and Walker, 1992; Maskell, 2001a), (ii) the evolution of economic and social processes in different contexts (Storper and Walker, 1989; Nelson, 1995), (iii) localised processes of innovation and knowledge creation (Dosi, 1988; Storper, 1997; Maskell, 2001b), (iv) the effects of communication and interaction between economic actors in the same or in different places (Gertler, 1993; 1995; Lundvall and Johnson, 1994). These aspects have been largely neglected in traditional approaches, even though they are at the core of understanding localised growth and globalisation tendencies in the knowledge-based economy (see, also, Hayter, 2004). Interactive learning, creative variation and collective knowledge generation can be viewed as micro-level processes which link the above dimensions of analysis. In a simplified way, we could argue that interaction between individuals within and between organisations yields innovations which, in turn, affect the structure of the constitutive organisations in a reflexive manner. This process results in an evolutionary dynamic.

Although they focus on contextuality, relational approaches are not to be confused with ideographic analyses of regions, such as in traditional area studies which emphasise the individuality of regions. As suggested by Sayer (2000), an important step in the realist methodology is to go beyond contextual description and identify common aspects of the 
causal mechanisms that affect economic action in spatial perspective. By way of decontextualisation, it is aimed to uncover the basic conditions of specific contexts. In this approach, economic geography is involved in theorising economic action. It is a pluralistic (Barnes, 2001) rather than a mere 'synthetic' discipline.

\section{Agency and rationalities}

An important question when analysing economic action is, of course, how actors should be included in research. At the core of a relational research program are those individuals who make economic decisions and interact with others in production and transaction processes or their institutional contexts, i.e. workers, managers, consumers and politicians. Their activities are generally purposeful, although they may have unintended consequences (e.g. Hudson, 2004). It is questionable, however, whether it is possible to limit the analysis to these individual actors. There are also collective actors, such as firms, governmental bodies and other organisations, which have to be considered. They differ from individuals and cannot be reduced to them (see, also, Maskell, 2001a; Oinas, 2005). Firms operate differently from individuals because managers and workers may perform particular roles in their business life and engage in complex processes of negotiation and decision making. Firms are also organised around routines which exist independently from the individual agents who operate inside these organisations (Nelson, 1995; Lawson and Lorenz, 1999).

The conceptual foundations of relational action are based on an institutional perspective (Amin, 1999). In this perspective, the goals and preferences of human action are not predetermined by the assumption that actors are rational, utility-maximising individuals (Hodgson, 2003). In reality, agents are embedded in structures of socio-institutional relations and actor-networks which influence their decisions and actions (Granovetter, 1985). They are, for instance, involved in specialised producer-user networks and cannot easily change their transaction partners and production program (Grabher, 1993). 
Further, there are various rationalities at work which yield differences in economic performance (Amin, 1999). Agents might choose between an instrumentalist rationality (focusing on reactive problem solving, e.g. in stable environments), procedural rationality (through which problems are broken down and solved in a stepwise manner) or recursive rationality (aiming to anticipate changes and actively shape the environment). The predominance of a particular rationality, of course, depends on the agents' contexts and experiences. ${ }^{11}$ At the same time, "... individuals engage in multiple networks associated with different rationalities, and these different networks ... [can be] overlapping networks" (Ettlinger, 2003: 161). Therefore, economic relations also include social, cultural and political aspects which affect decisions. As opposed to traditional approaches, the relational conception suggested in this paper is capable of integrating multiple rationalities and complex contexts of economic action. Multiplex relations result which link people in many different ways as neighbours, friends and business partners (Uzzi, 1997). These provide a means of engaging resources from one type of relation to another and transfer institution-based capacity trust into personal emotive trust and vice versa. Economic, social and cultural relations define a creative field which stimulates entrepreneurship, learning and innovation within regional agglomerations and between them (Scott, 2004).

There is a tendency, however, within some of the literature on regional networks and the 'cultural turn' to overemphasise the social and neglect the economic. At least implicitly, networks are sometimes portrayed as if they were ultimately democratic, consisting of altruistic agents who engage in friendly networks. Despite the importance of the socioinstitutional context, a relational conceptualisation cannot neglect the fact that economic agents are generally interested in enhancing their personal wealth (Taylor, 2004). Therefore, competition and rivalry are important aspects which shape economic action in relational perspective. 
In sum, the relational approach suggests that economic agents act according to particular economic and non-economic goals and strategies, as well as feelings and emotions (Ettlinger, 2004; Massey, 2004). The results of this intentional action encompass intended and unplanned spatial outcomes which, in turn, impact the next round of decisions (Werlen, 1995; Bathelt and Glückler, 2003). I would, thus, argue that a micro perspective of human action should be applied to economic geography which emphasises its contextual, path-dependent and contingent nature. This also implies that general spatial laws of economic action do not exist.

\section{Institutions and the micro-macro dilemma}

The relational view presented is particularly well-suited to analyse institutions in thematic, methodological and ontological terms (Jessop, 2001). Institutions can be understood as stabilised forms of social relations which are produced recursively through relational action. Efficient communication between transaction partners in a particular environment requires the development of a shared context of formal and informal institutions. This enables specialised users and producers to discuss and solve problems (North, 1991; Hodgson, 1998). Such a framework does not, however, exist spontaneously. In a cluster, for instance, joint problemsolving and experimentation help create preliminary solutions which must be robust enough to survive the next series of interactions (Storper, 1997).

Often conventions, accepted rules, norms, common standards, habits, shared heuristics and technology attitudes are shaped to some degree by the settings negotiated at the level of the nation-state (Lundvall and Maskell, 2000; Bathelt, 2003). Even with economic globalisation, the nation-state still has an impact on the conditions under which firms take part in and benefit from these processes. At the same time, globalisation increasingly shapes processes of institution building and challenges the boundaries of the nation-state. In the context of regional production, institutional conditions are also of great importance to enable 
inter-firm collaboration (Amin, 1999; Asheim and Isaksen, 2002) by translating and adjusting national conditions to regional specificities.

This suggests that different layers of institutions support or work against one another. Storper (2004), for instance, argues that the relation between community and society institutions is decisive in understanding why some places grow faster than others. In addition to these institutional levels, Clark, Tracey, and Lawton Smith (2001) emphasise the context of family inheritance for regional development (see, also, Bathelt and Boggs, 2005). These endowments and inheritances include institutions and routines at different scales that support interactive learning. Family inheritance refers to the regional firms' accumulated capabilities and describes the overall ability of all firms in a region to learn individually. In contrast, community inheritance is the overall capacity for interaction and learning between the firms of a region, while society endowments refer to overall societal opportunities and restrictions for interaction. In the short run, these inheritances are more-or-less fixed and cannot be changed by individual actors. Territorial policies can impact processes of economic development in the longer run by (re)defining institutional conditions at these different levels. They create a set of nested scales which are neither hierarchical nor deterministic (Swyngedouw, 1997). Economic action and interaction are mediated through and between these scales because activities take place at various scales simultaneously and thus have multi-scalar influences (Bunnell and Coe, 2001).

The relational perspective does not rule out macro-theoretical considerations because human agency is, of course, not independent from the conditions of the capitalist system. Institutions serve to mediate between both the micro and macro level (Jessop, 2001). They create a connection between the wider societal structures and economic agency. This also helps understand the relationship between local and global forces (e.g. Clark, 2005). On the one hand, institutions shape economic practices and should, thus, be studied at the level of the 
economic actor (Hodgson, 1998). On the other hand, the institutional context motivates ongoing relations between agents and enables these to be reproduced. This, in turn, impacts the institutional conditions of economic action. Overall, a reflexive process of economic action and institution-building can be conceptualised (see, also, Hudson, 2004). This process also involves influences of the macro structures of the capitalist system which are transferred to the individual level through institutions in a process of downward causation. At the same time, there is also a process of upward causation (Hodgson, 2003). This process describes how micro practices are translated into broader institutional arrangements which affect the macro level.

Giddens (1984) has described these processes in his theory of structuration as a reflexive relationship between structure and agency. This does not mean that structure determines agency and vice versa, creating a vicious circle without any explanatory significance, as some critics have argued. Rather, interdependence between institutions and agency results in progressive development, where institutions mediate between the individuals and wider societal structures. ${ }^{12}$ As Murdoch (1995) has warned, however, there is a danger in constructing macro explanations to interpret micro-scale processes without much empirical evidence. Therefore, I argue that any macro-theoretical analysis should encompass a strong micro-scale basis.

\section{Relational policies}

In this report, I have argued that the recent trend toward a relational conceptualisation should not be seen as yet another turn in economic geography, which emphasises some aspects of economic life while neglecting others. Such a conceptualisation involves a strong actor perspective, integrates economic, social, cultural and political influences on economic action, rejects deterministic interpretations related to spatial categories and, instead, emphasises the importance of a spatial perspective in analyses. 
Taking this approach seriously, a variety of issues arise which have, in my view, important consequences for the conceptualisation of regional or local policy making. One direct outcome of the discussion is that general policies cannot be developed like recipes which always work if all the ingredients are at hand. As argued above, relational policies should be based on an evolutionary and contextual understanding of economic action, which cannot direct regional futures in a deterministic way.

A relational policy takes existing regional structures and strengths into account as a starting point for the development of initiatives. Traditional top-down policies, which focus on the provision of unspecific infrastructure, typically provide land for industrial development or grant general subsidies for individual investments (Amin, 1999). From a relational view, it is clear that policy initiatives cannot be simply superimposed upon regional agents by policy makers and planners. Any initiative should be bottom-up and enrol the most important and dynamic actors or would be doomed to fail (Bathelt, 2005b). Of course, such involvement cannot be expected to happen spontaneously; there is no guaranteed success. It is a timely process which requires that the participants learn to incorporate collective matters of interest into their strategies. As a consequence, policy makers ought to become mediators and boundary-spanners rather than creators and dominators, when developing a democratic policy program and negotiating between the actors involved.

The goal of this policy would be to strengthen localised capabilities (Maskell and Malmberg, 1999) or competencies in activating existing assets and combining them with new knowledge. Among other things, this would encompass the provision of support in processes of institution building, network generation, firm formation, interactive learning and enrolment in joint actions. It does not, of course, mean that all conventional policy programs are obsolete. Rather, it seems useful to combine different policies and stimulate diversity to create a wide range of opportunities for regional development paths (Amin, 1999). 
An important aspect of a relational policy is related to the combination of global and local forces. While regional policy traditionally draws upon regional assets to produce competitiveness, the value of this becomes questionable in the era of globalisation. As Amin (2004) has pointed out, spatial configurations are not necessarily territorial in character. That part of the local which is primarily produced locally is obviously decreasing. Economic agents travel around the world and develop international business networks; the local labour market is shaped by trans-national migration; and the local knowledge base is constantly shaped by news reports and experiences from other parts of the world. A relational reading of place, thus, requires that we give up the idea of an encapsulated local and accept that the global exists and develops inside the local (Amin, 2004; Massey, 2004). ${ }^{13}$

This has fundamental consequences for policy making. First, international flows, connectivities and multiple geographical expressions become the focus of regional policy, instead of static regional characteristics. Second, regions can no longer be viewed as autonomous entities which are capable of determining their own futures, merely based on their internal strengths. Production and knowledge networks are not limited to the local. Further, regional policies cannot fully control these new transient spaces (see, also, Bathelt, 2003). Third, instead of protecting the seemingly coherent local against the contradictory global, regional policy has to become a policy of local activation and enrolment in the global. As suggested by Bathelt and Boggs (2005), agents should be encouraged to re-bundle local and non-local assets to systematically connect the local and global spheres. Fourth, this does not mean that the local is governed by a global logic which does not leave room for local initiatives. Regional policy will, however, have to go beyond a narrow territorial basis and enter wider policy arenas to negotiate arguments and claims.

I would argue that a relational conceptualisation of economic geography sheds new light on global interdependencies and their interrelations with local processes and specificities. 
Even though "[t]here is no definable regional territory to rule over", as Amin (2004: 36) has emphasised, a policy which focuses on trans-local connections instead of territorial structures is yet utopia rather than reality. Clearly, policy initiatives should be directed toward both the generation of local networks to provide opportunities for local synergies and recombinations and the formation of trans-local 'pipelines' to secure knowledge inputs and access to longerterm growth potentials.

\section{Acknowledgements}

Earlier versions of this paper were presented in 2005 at the Annual Meeting of the Association of American Geographers in Denver and the Inaugural Nordic Geographers Meeting on 'Power over Time-Space' in Lund, Sweden. I would particularly like to thank John Allen, Bjørn Asheim, Trevor Barnes, Gordon Clark, Johannes Glückler, Andrew Sayer and Clare Wiseman for providing constructive comments on some ideas central to this report.

\section{Notes}

${ }^{1}$ Recently, Boschma and Frenken (2005) have suggested yet another turn toward evolutionary economic geography.

${ }^{2}$ There is a danger that recent work of the proximity school (Rallet and Torre, 1999) could be interpreted and applied in a similar way (see, also, Boschma, 2005).

${ }^{3}$ Barnes (2001) describes this as a shift from a narrow quantitative approach towards a reflexive and interpretative understanding in economic geography, without trying to identify the commonalities of the new ways of thinking.

${ }^{4}$ It should be mentioned that the discourse about the conceptualisation of economic geography is also characterised by a debate about the methods which should be used when conducting empirical studies. Proponents of cultural and relational approaches have emphasised the need for qualitative, interpretative work (e.g. Schoenberger, 1997), while advocates of geographical economics clearly prioritise quantitative, statistical data analysis, sometimes without much reasoning (Overman, 2004). Here, I would like to avoid proposing 
another dualism. From a relational perspective, the choice of a suitable methodological approach depends upon the particular research questions to be answered. The importance of qualitative methods has, however, increased over time as research focuses more strongly on motivations and strategies of and processes behind human agency.

${ }^{5}$ Others, such as Nancy Ettlinger, have gone a similar route in a different context (e.g. Ettlinger, 2003; 2004).

${ }^{6}$ As argued by Olivier Crevoisier, the French-Swiss milieu school applies a conceptualisation similar to this (Crevoisier, 2001; 2004).

${ }^{7}$ In the case of Spanish economic geography, Sánchez Hernández (2003) has developed a conceptualisation, referred to as the structural-contextual project, which draws upon similar ideas and propositions.

${ }^{8}$ This was also supported by the views of some economic, social, cultural and political geographers in Germany, such as Christian Berndt, Paul Reuber, Eike Schamp and Benno Werlen (e.g. Werlen, 1995; 2003; Schamp, 2000; Reuber, 2002; Berndt, 2003).

${ }^{9}$ These sessions were an outcome of joint concerns expressed during the 2001 AAG meetings in New York, as well as the discussions with Jeff Boggs during his research stay in Frankfurt/Main later on that year, where Johannes Glückler and I were based at that time.

${ }^{10}$ This development has largely been dominated by a Euro-/Anglo-American-centric perspective. References to African contexts or Asian views have, for instance, been relatively rare (e.g. Lee, 2001; Murphy, 2003; Yeung and Lin, 2003).

${ }^{11}$ The argument here is that it is important to include both the individual motivations of economic agents and the socio-institutional contexts of their actor-networks, instead of primarily focusing on the latter relationships as suggested by Yeung (2005).

${ }^{12}$ See, also, Jessop's (2001) structural-relational approach.

${ }^{13}$ This implies that the way how power is established and exercised over distance between nation-states and different cultural and institutional contexts becomes a key issue of analyses in economic geography (Allen, 2003; 2004; see, also, Schoenberger, 1997; Depner and Bathelt, 2004; Yeung, 2005).

\section{References}

Allen, J. 2003: Lost geographies of power. Malden (MA), Oxford: Blackwell. 
Allen, J. 2004: The whereabouts of power: politics, government and space. Geografiska Annaler 86 B, 19-32.

Amin, A. 1994: Post-Fordism. Oxford, Cambridge (MA): Blackwell.

Amin, A. 1999: An institutionalist perspective on regional economic development. International Journal of Urban and Regional Research 23, 365-378.

Amin, A. 2002: Moving on: institutionalism in economic geography. Environment and Planning A 33, 1237-1242.

Amin, A. 2004: Regions unbound: towards a new politics of place. Geografiska Annaler 86 B, $33-44$.

Amin, A. and Cohendet, P. 2004: Architectures of knowledge: firms, capabilities, and communities. Oxford, New York: Oxford University Press.

Amin, A. and Thrift, N. 2000: What kind of economic theory for what kind of economic geography. Antipode 32, 4-9.

Amin, A. and Thrift, N., editors 2003: The Blackwell cultural economy reader. Oxford: Blackwell.

Asheim, B. T. and Herstad, S. J. 2003: Regional innovation systems and the globalising world economy. Spatial Aspects Concerning Economic Structures Working Paper (SPACES) 2003-12. Marburg: Faculty of Geography, Philipps-University of Marburg (URL: http://www.uni-marburg.de/geographie/spaces, date accessed: 27 May 2005).

Asheim, B. T. and Isaksen, A. 2002: Regional innovation systems: the integration of local 'sticky' and global 'ubiquitous' knowledge. Journal of Technology Transfer 27, 77-86.

Barnes, T. J. 2001: Retheorizing economic geography: from the quantitative revolution to the 'cultural turn'. Annals of the Association of American Geographers 91, 546-565.

Bathelt, H. 2001: Warum Paul Krugmans Geographical Economics keine neue Wirtschaftsgeographie ist! (Why Paul Krugman's geographical economics is not a new economic geography!). Die Erde 132, 107-118.

Bathelt, H. 2003: Geographies of production: growth regimes in spatial perspective 1 Innovation, institutions and social systems. Progress in Human Geography 27, 763-778.

Bathelt, H. 2005a: Geographies of production: growth regimes in spatial perspective 2 Knowledge creation and growth in clusters. Progress in Human Geography 29, 204-216.

Bathelt, H. 2005b: Cluster relations in the media industry: exploring the 'distanced neighbour' paradox in Leipzig. Regional Studies 39, 105-127.

Bathelt, H. and Boggs, J. S. 2005: Continuities, ruptures and re-bundling of regional development paths: Leipzig's metamorphosis. In Fuchs, G. and Shapira, P., editors, 
Rethinking regional innovation and change: path dependency or regional breakthrough?, New York: Springer, 147-170.

Bathelt, H. and Glückler, J. 2002: Wirtschaftsgeographie: Ökonomische Beziehungen in räumlicher Perspektive (Economic geography: economic relations in spatial perspective). Stuttgart: UTB - Ulmer.

Bathelt, H. and Glückler, J. 2003: Toward a relational economic geography. Journal of Economic Geography 3, 117-144.

Berndt, C. 2003: El Paso del Norte ... Modernization utopias, othering and management practices in Mexico's maquiladora industry. Antipode 35, 264-285.

Boggs, J. S. and Rantisi, N. M. 2003: The 'relational' turn in economic geography. Journal of Economic Geography 3, 109-116.

Boschma, R. A. 2005: Proximity and innovation: a critical assessment. Regional Studies 39, $61-74$.

Boschma, R. A. and Frenken, K. 2005: Why is economic geography not an evolutionary science? Towards an evolutionary economic geography. Papers in Evolutionary Economic Geography (PEEG) 05-01. Utrecht: Urban and Regional Research Centre Utrecht, Utrecht University (URL: http://econ.geog.uu.nl/peeg/peeg.html, date accessed: 6 May 2005).

Bunnell, T. G. and Coe, N. M. 2001: Spaces and scales of innovation. Progress in Human Geography 25, 569-589.

Capello, R. and Faggian, A. 2005: Collective learning and relational capital in local innovation processes. Regional Studies 39, 75-87.

Clark, G. L. 1983: Fluctuations and rigidities in local labor markets. Part 2: reinterpreting relational contracts. Environment and Planning A 15, 365-377.

Clark, G. L. 2005: Beyond close dialogue: economic geography as if it matters. Economic Geography Research Group Working Papers WPG 05-04. Oxford: School of Geography and the Environment, Oxford University (URL:

http://www.geog.ox.ac.uk/research/wpapers/economic/index.html, date accessed: 20 May 2005).

Clark, G. L. and Tracey, P. 2004: Global competitiveness and innovation: an agent-centred perspective. Houndsmill, New York: Palgrave Macmillan.

Clark G. L., Tracey P. and Lawton Smith H. (2001): Agents, endowments, and pathdependence: a model of multi-jurisdictional regional development. Geographische Zeitschrift 89, 166-181. 
Coe, N. M. and Bunnell, T. G. 2003: 'Spatializing' knowledge communities: towards a conceptualisation of transnational innovation networks. Global Networks 3, 437-456.

Cooke, P. and Morgan, K. 1998: The associational economy. Oxford: Oxford University Press.

Crang, P. 1997: Cultural turns and the (re)constitution of economic geography. In Lee, R. and Wills, J., editors, Geographies of economies, London, New York: Arnold, 3-15.

Crevoisier, O. 2001: Der Ansatz des kreativen Milieus: Bestandsaufnahme und Forschungsperspektiven am Beispiel urbaner Milieus (The creative milieu: state of the art, research perspectives and the case of urban milieus). Zeitschrift für Wirtschaftsgeographie 45, 246-256.

Crevoisier, O. 2004: The innovative milieus approach: toward a territorialized understanding of the economy? Economic Geography 80, 367-379.

Depner, H. and Bathelt, H. 2005: Exporting the German model: the establishment of a new automobile industry cluster in Shanghai. Economic Geography 81, 53-81.

Dicken, P. 2005: Tangled webs: transnational production networks and regional integration. Spatial Aspects Concerning Economic Structures Working Paper (SPACES) 2005-04. Marburg: Faculty of Geography, Philipps-University of Marburg (URL: http://www.uni-marburg.de/geographie/spaces, date accessed: 16 June 2005).

Dicken, P., Kelly, P. F., Olds, K. and Yeung, H. W.-c. 2001: Chains and networks, territories and scales: towards a relational framework for analysing the global economy. Global Networks 1, 89-112.

Dicken, P. and Malmberg, A. 2001: Firms in territories: a relational perspective. Economic Geography 77, 345-363.

Dosi, G. 1988: The nature of the innovative process. In Dosi, G., Freeman, C., Nelson, R. R., Silverberg, G. and Soete, L. L. G., editors, Technical change and economic theory, London, New York: Pinter, 221-238.

Ettlinger, N. 2003: Cultural economic geography and a relational and microspace approach to trusts, rationalities, networks, and change in collaborative workplaces. Journal of Economic Geography 3, 145-172.

Ettlinger, N. 2004: Toward a critical theory of untidy geographies: the spatiality of emotions in consumption and production. Feminist Economics 10 (3), 21-54.

Fujita, M., Krugman, P. and Venables, A. 1999: The spatial economy: cities, regions, and international trade. Cambridge (MA): MIT Press.

Gertler, M. S. 1993: Implementing advanced manufacturing technologies in mature industrial 
regions: towards a social model of technology production. Regional Studies 27, 665-680.

Gertler, M. S. 1995: 'Being there': proximity, organization, and culture in the development and adoption of advanced manufacturing technologies. Economic Geography 71, 1-26.

Gertler, M. S. 2004: Manufacturing culture: the institutional geography of industrial practice. Oxford, New York: Oxford University Press.

Giddens, A. 1984: The constitution of society. Outline of the theory of structuration. Cambridge: Polity Press.

Glückler, J. 1999: Neue Wege geographischen Denkens? Eine Kritik gegenwärtiger Raumkonzepte und ihrer Forschungsprogramme in der Geographie (New ways of geographical reasoning? A critique of contemporary conceptions of space and research designs in geography). Frankfurt/Main: Verlag Neue Wissenschaft.

Glückler, J. and Bathelt, H. 2003: Zur Bedeutung von Ressourcen in der relationalen Wirtschaftsgeographie: Von einer substanzialistischen zu einer relationalen Perspektive (The importance of resources in relational economic geography: from substantive concepts towards a relational perspective). Zeitschrift für Wirtschaftsgeographie 47, 249-267.

Grabher, G. 1993: Rediscovering the social in the economics of interfirm relations. In Grabher, G., editor, The embedded firm. On the socioeconomics of industrial networks, London, New York: Routledge, 1-31.

Grabher, G. 2002: Cool projects, boring institutions: temporary collaboration in social context. Regional Studies 36, 205-214.

Granovetter, M. 1985: Economic action and economic structure: the problem of embeddedness. American Journal of Sociology 91, 481-510.

Hayter, R. (2004): Economic geography as dissenting institutionalism: the embeddedness, evolution and differentiation of regions. Geografiska Annaler 86 B, 95-115.

Henderson, J., Dicken, P., Hess, M., Coe, N. and Yeung, H. W.-c. 2002: Global production networks and the analysis of economic development. Review of International Political Economy 9, 436-464.

Hodgson, G. M. 1998: The approach of institutional economics. Journal of Economic Literature 36, 166-192.

Hodgson, G. M. 2003: The hidden persuaders: institutions and individuals in economic theory. Cambridge Journal of Economics 27, 159-175.

Hudson, R. 2004: Conceptualizing economies and their geographies: spaces, flows and circuits. Progress in Human Geography 28, 447-471. 
Jessop, B. 2001: Institutional re(turns) and the strategic-relational approach. Environment and Planning A 33, 1213-1235.

Krugman, P. 1991: Geography and trade. Leuven: Leuven University Press; Cambridge (MA), London: MIT Press.

Lawson, C. and Lorenz, E. 1999: Collective learning, tacit knowledge and regional innovative capacity. Regional Studies 33, 302-317.

Lee, J. H. 2001: Geographies of learning and proximity reconsidered: a relational/organizational perspective. Journal of the Korean Geographical Society 36, 539-560.

Lee, R. 2002: 'Nice maps, shame about the theory'? Thinking geographically about the economic. Progress in Human Geography 26, 333-355.

Lundvall, B.-Å. and Johnson, B. 1994: The learning economy. Journal of Industry Studies 1, $23-42$.

Lundvall, B.-Å. and Maskell, P. 2000: Nation states and economic development: from national systems of production to national systems of knowledge creation and learning. In Clark, G. L., Feldman, M. P. and Gertler, M. S., editors, The Oxford handbook of economic geography, Oxford: Oxford University Press, 353-372.

Malmberg, A. and Maskell, P. 2002: The elusive concept of localization economies: towards a knowledge-based theory of spatial clustering. Environment and Planning A 34, 429449 .

Martin, R. and Sunley, P. 1996: Paul Krugman's geographical economics and its implications for regional development theory: a critical assessment. Economic Geography 74, 259292.

Martin, R. and Sunley, P. 2001: Rethinking the 'economic' in economic geography: broadening our vision or losing our focus? Antipode 33, 148-161.

Maskell, P. 2001a: The firm in economic geography. Economic Geography 77, 329-344.

Maskell, P. 2001b: Towards a knowledge-based theory of the geographical cluster. Industrial and Corporate Change 10, 921-943.

Maskell, P. and Malmberg, A. 1999: The competitiveness of firms and regions: 'ubiquitification' and the importance of localized learning. European Urban and Regional Studies 6, 9-25.

Massey, D. 1985: New directions in space. In Gregory, D. and Urry, J., editors, Social relations and spatial structures, Basingstoke: Macmillan, 9-19.

Massey, D. 2004: Geographies of responsibility. Geografiska Annaler 86 B, 5-18. 
Murdoch, J. 1995: Actor-networks and the evolution of economic forms: combining description and explanation in theories of regulation, flexible specialization, and networks. Environment and Planning A 27, 731-757.

Murphy, J. T. 2003: Social space and industrial development in East Africa: deconstructing the logics of industry networks in Mwanza, Tanzania. Journal of Economic Geography 3, 173-198.

Nelson, R. R. 1995: Evolutionary theorizing about economic change. Journal of Economic Literature 23, 48-90.

North, D. C. 1991: Institutions. The Journal of Economic Perspectives 5, 97-112.

Oinas, P. (2005): The firm and its many boundaries. In Taylor, M. and Oinas, P., editors, Conceptualising the firm: capabilities, cultures, and conditions, Oxford: Oxford University Press, forthcoming.

Overman, H. G. 2004: Can we learn anything from economic geography proper? Journal of Economic Geography 4, 501-516.

Polanyi, K. 1957: The economy as instituted process. In Polanyi, K., Arensberg, C. M. and Pearson, H. W., editors, Trade and market in the early empires, Glenco: Free Press, 243-270.

Rallet, A. and Torre, A. 1999: Is geographical proximity necessary in the innovation networks in the era of the global economy? GeoJournal 49, 373-380.

Reuber, P. 2002: Die Politische Geographie nach dem Ende des Kalten Krieges - Neue Ansätze und aktuelle Forschungsfelder (New approaches and research fields in political geography after the Cold War). Geographische Rundschau 54 (7-8), 4-9.

Rodríguez-Pose, A. 2001: Killing economic geography with a 'cultural turn' overdose. Antipode 33, 176-182.

Sánchez Hernández, J. L. 2003: Naturaleza, localización y sociedad: tres enfoques para la geografía ecónomica. Salamanca: Ediciones Universidad de Salamanca.

Sayer, A. 1992: Method in social science. London: Routledge.

Sayer, A. 2000: Realism and social science. London: Sage.

Sayer, A. and Walker, R. 1992: The new social economy: reworking the division of labor. Cambridge (MA), Oxford: Blackwell.

Schamp, E. W. 2000: Vernetzte Produktion: Industriegeographie aus institutioneller Perspektive (Networked production: industrial geography from institutional perspective). Darmstadt: Wissenschaftliche Buchgesellschaft.

Schoenberger, E. 1997: The cultural crisis of the firm. Cambridge (MA), Oxford: Blackwell. 
Sheppard, E. 2000: Geography or economics? Conceptions of space, time, interdependence, and agency. In Clark, G. L., Feldman, M. P. and Gertler, M. S., editors, The Oxford handbook of economic geography, Oxford: Oxford University Press, 99-119.

Scott, A. J. 1988: New industrial spaces: flexible production organization and regional development in North America and Western Europe. London: Pion.

Scott, A. J. 2000: Economic geography: the great half-century. Cambridge Journal of Economics 24, 483-504.

Scott, A. J. 2004: A perspective of economic geography. Journal of Economic Geography 4, 479-499.

Storper, M. 1997: The regional world: territorial development in a global economy. New York, London: Guilford.

Storper, M. 2004: Society, community and economic development. In Gebhardt, H. and Meusburger, P., editors, Hettner-Lecture 2003 with Michael Storper 'Institutions, incentives and communication in economic geography', Stuttgart: Steiner, 7-39.

Storper, M. and Venables, A. J. 2004: Buzz: face-to-face contact and the urban economy. Journal of Economic Geography 4, 351-370.

Storper, M. and Walker, R. 1989: The capitalist imperative. Territory, technology, and industrial growth. New York, Oxford: Basil Blackwell.

Swyngedouw, E. 1997: Neither global nor local: 'glocalization' and the politics of scale. In Cox, K. R., editor, Spaces of globalization: reasserting the power of the local. New York, London: Guilford, 137-166.

Taylor, M. J. 2004: The firm as a connected, temporary coalition. Spatial Aspects Concerning Economic Structures Working Paper (SPACES) 2004-05. Marburg: Faculty of Geography, Philipps-University of Marburg (URL: http://www.unimarburg.de/geographie/spaces, date accessed: 15 May 2005).

Thrift, N. 2000a: Pandora's box? Cultural geographies of economies. In Clark, G. L., Feldman, M. P. and Gertler, M. S., editors, The Oxford handbook of economic geography. Oxford: Oxford University Press, 689-704.

Thrift, N. 2000b: Performing cultures in the new economy. Annals of the Association of American Geographers 90, 674-692.

Uzzi, B. 1997: Social structure and competition in interfirm networks: the paradox of embeddedness. Administrative Science Quarterly 42, 35-67.

van Wezemael, J. 2004: Erkenntnis und Interesse: Zur handlungstheoretischen Wirtschaftsgeographie am Beispiel der Sanierung genossenschaftlicher Wohnbauten 
(Towards an agency-based conceptualisation of economic geography: the case of housing co-operatives). Geographica Helvetica 59, 81-92.

Walker, R. and Storper, M. 1981: Capital and industrial location. Progress in Human Geography 5, 473-509.

Werlen, B. 1995: Sozialgeographie alltäglicher Regionalisierungen. Band 1: Zur Ontologie von Gesellschaft und Raum (Social geography of every day's regionalisations. Vol. 1: Ontology of society and space). Stuttgart: Steiner.

Werlen, B. 2003: Kulturgeographie und kulturtheoretische Wende (Cultural geography and cultural turn). In Gebhardt, H., Reuber, P. and Wolkersdorfer, G., editors, Kulturgeographie: Aktuelle Ansätze und Entwicklungen (New approaches and developments in cultural geography). Heidelberg, Berlin: Spektrum, 251-268.

Yeung, H. W.-c. 1998: The socio-spatial constitution of business organizations: a geographical perspective. Organization 5, 101-128.

Yeung, H. W.-c. 2005: Rethinking relational economic geography. Transactions of the Institute of British Geographers NS 30, 37-51.

Yeung, H. W.-c. and Lin, G. C. S. 2003: Theorizing economic geographies of Asia. Economic Geography 79, 107-128. 
